Lebedev, S.V. (2020). The Ostsee issue in the second half of the 19th century. Historical values and problems of their interpretation. Collection of Scientific Articles. European Scientific e-Journal, 5 (5), 27-38. Hlučín-Bobrovníky: "Anisiia Tomanek" OSVČ.

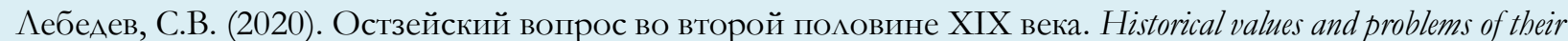
interpretation. Collection of Scientific Articles. European Scientific e-Journal, 5 (5), 27-38. Hlučín-Bobrovníky: "Anisiia Tomanek" OSVČ.

DOI: $10.47451 /$ his2020-12-004

EOI: $10.11244 /$ his2020-12-004

The paper is published in Crossref, Internet Archive, Google Scholar, Academic Resource Index ResearchBib, JGate, ISI, CiteFactor, ICI, eLibrary databases.

\author{
Sergey $V$. Lebedev \\ Full Professor, Doctor of Philosophical Sciences \\ Head of the Department of Philosophy \\ High School of Folk Arts (Academy) \\ St Petersburg, Russia \\ E-mail: servicleb@list.ru \\ ORCID: 0000-0002-7994-2660
}

\title{
The Ostsee issue in the second half of the 19th century
}

\section{Abstract:}

In the second 19th century, one of the most acute issues in the internal Russian polemics was the question of the Ostsee (Baltic). This region had a kind of autonomy, being three self-governing Russian provinces. The indigenous people (who in the second half of the century before last acquired the names of Estonians and Latvians) were even legally considered second-class people. Russian publicists of the conservative direction, speaking out against the special order of administration of the region, largely contributed to the national development of local nationalities. This article shows the role and significance of Russian conservative publicists who fought against the German (Ostsee) orders in the region. The results of this struggle are also shown, during which it became possible to talk about the formation of the Baltic Nations from the totality of the lower classes.

Keywords:

Ostsee issue, Baltic provinces, Prussia, Katkov, Aksakov, Rohrbach, Moscow Vedomosti.

Сергей Викторович Аебедев профессор Аоктор философских наук зав. кафедрой философии Высшая школа народных искусств (Академия)

Санкт-Петербург, Россия

E-mail: servicleb@list.ru

ORCID: 0000-0002-7994-2660

\section{Остзейский вопрос во второй помовине XIX века}

\section{Аннотачия:}

Во второй XIX века одним из самых острых вопросов во внутрироссийской полемике был вопрос остзейский (прибалтийский). Этот край имел своеобразную автономию, явАяясь тремя самоуправляемыми российскими губерниями. Коренные жители (которые именно во второй 


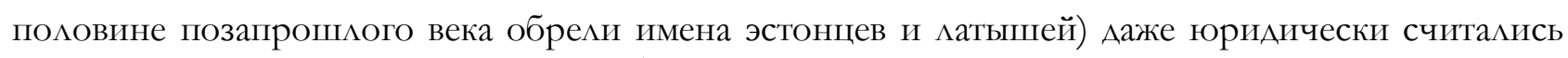
Аюдьми второго сорта. Российские публицисты консервативного направления, выступая против особого порядка управления краем, во многом способствовали национальному развитию местных народностей. В Аанной статье показывается роль и значение русских консервативных публицистов, которые вели борьбу против немецких («остзейских») порядков в крае. Также показаны результаты этой борьбы, в ходе которой и стало возможным говорить о формировании прибалтийских наций из совокупности низших сословий.

Клточевие слова:

отсзейский вопрос, прибалтийский губернии, Пруссия, Катков, Аксаков, Рорбах, Московские ведомости.

\section{Introduction}

One of the most important issues of Russian life in the second half of the 19th century was the so-called Ostsee Issue. The three Baltic provinces of Estonia, Courland and Livonia (now the territory of Estonia and Latvia) were called the Ostsee region. The name was derived from the German name for the Baltic sea, which the Germans call the East Sea (Ostsee). The Ostseisians, i.e., a special ethno-territorial group of Russian Germans, or rather the highest of the Baltic nobility, ruled the region. The Ostseisians were not a nation, but only a corporate system of privileged estates in the Baltic provinces. From the 13th to 17th centuries, they were the most dangerous opponents of Russia. After the annexation of the Ostsee region to Russia under Peter the Great, they were the most loyal category of Russian subjects for two centuries. The history of the Ostsee Germans began in the 13th century when the "dog-knights" conquered and actually turned into a slave state the indigenous peoples of the region - the Finno-Ugric tribes, whose descendants later became called Estonians, as well as the tribes of the Balts, the ancestors of the Latvians, close to the Slavs. In general, the Ostsee nobility had been fully formed until the 18th century, but in general terms, the vassals of the Livonian Order and the archbishops formed a class corporation soon after the conquest.

1.

After the Livonian war, the Order collapsed, but Sweden and Poland, which took possession of the Baltic lands, preserved all the rights and privileges of the German barons and burghers in inviolability. The barony also organically included representatives of some Swedish (e.g., the Wrangels), Scottish (Barclay de Tolly) and Russian families (e.g., the von Andrianov, von Baranov, and von Arbuzov families are known), who became one hundred per cent ostzeits. As early as the 17 th century, pastor Hupel wrote that in this region "everyone who is not a peasant is called a German, and even if he cannot speak a word of German, for example, the English and Russians. To this class belong the 
landlords, the literati, the landlords, the free servants, and even the freedmen, as soon as they put on German clothes."

Having annexed Livonia and Estland, Peter the Great retained all the old privileges for the local German barons and burghers, including the estate system of noble administration and court. Courland, which was annexed to Russia in 1795, also retained the old system of government, unchanged from the time of the Duchy of Courland. The Ostsee Germans under Russian power ruled the Baltic States in the same way as in the 13th century.

In this region, there was a special legal regime different from the system of the Russian statehood and characterized by the dominance of the German language, Lutheranism, a special set of laws (of Baltic law), court management, etc. functions of internal administration was carried out by organs of the German nobility. The governor of any of the three Ostsee provinces, who was a representative of the central government, until the beginning of the first world war, was forced to build his official activities so as not to violate the privileges of the nobility.

\section{2.}

The struggle for the solution of the Ostsee issue in the form of the final incorporation of the region into Russia took place in particularly paradoxical circumstances, given that Alexander the Second, the Emperor of All Russia, whose mother was the Prussian Princess Charlotte (Alexandra Feodorovna in Orthodoxy), and who was married to Maria of Hesse and a firm Germanophile. In the reign of Alexander II, the dominance of the Ostsee barons continued to persist. There was a good example that an employee of the newspaper Moskovskie Vedomosti, edited by the leading Russian publicist M.N. Katkov, Latvian Krišjānis Valdemārs published an article under the title Who rules Russia: the Russians themselves or the Germans? It gave the following figures: Germans were 15\% ministers, 25\% of the State Council's members, $40 \%$ senators, $50 \%$ generals, and $60 \%$ governors. Since the governors ran Russia, this was the answer to the question. Since all empresses were German, it was natural that through their patronage the Germans infiltrated the higher administration. Katkov, having read the article with amazement, did not believe in these figures. Then he told the Secretary to check them out. The results of the audit showed that the German senators were not 40, but as much as $63 \%$. However, Katkov published Valdemārs's article, replacing only the words of the empresses to the "higher officials".

Many Russian-born influential dignitaries were actually bribed by the Ostseisians. As an example, the former governor of Courland, and at the beginning of the reforms - the Minister of Internal Affairs P.A. Valuev, whose mother was a Baltic German woman, nee von Brinken, owned an estate in Courland. Valuev played a prominent role in the period of Great Reforms, but not in the Ostsee issue. The protection of the rights of the Ostsee 
barons remained unchanged for him at all times and in all the posts that he held. Another prominent figure of the era, actually the second person in the country at one time, P.A. Shuvalov was listed in matrikulas as a Baltic nobleman. As a result, both of these prominent figures of the era of the Great Reforms took quite pro-German positions in the Ostsee issue.

Thus, the opponents of the Ostsee order had to overcome the stubborn resistance not only of the Ostsee nobility but also of the highest spheres of the Empire.

3.

Among the many paradoxes of Russian life in the century before last was the existence of a fairly free press under the autocracy. Due to the clear political circumstances, there could not be an open political struggle in the form of parliamentary debates or the activities of political parties in Russia at that time. The social and political struggle was carried on in the press, and, of course, there could be no official party press. Political programs and manifestos of various ideological trends were presented in the form of journalism "on the topic of the day", fiction and criticism. Hence it is clear why it was 'thick' magazines that replaced the parliament, parties, and university departments of philosophy in Russia. However, some newspapers were also able to acquire a similar political significance. It is no accident that at that time, expressions such as the Party of Moscow Vedomosti were used to refer to conservatives or the Direction of Sovremennik for radicals. In fact, the role of party organs was played by the Slavophile newspapers Moscow and Moskvich (Muscovite), edited by Ivan Aksakov. The liberals were also represented by various editions. Finally, the serfs also had their newspaper Vesti, a favourite reading of the 'wild landlords'. A fierce magazine war raged between these editions. The Baltic problems found the widest coverage on the pages of publications. At the same time, the radicals were interested in the Ostsee issue only as a reason for additional criticism of the German dominance in the state apparatus of the country. The liberals, paradoxically at first glance, were inclined to defend the Ostseisians, admiring their 'civility' and regional self-government. It is clear that the serfs were delighted with the power of the Ostsee barons and were not averse to establishing an oligarchic rule, in which the monarch would have resembled a ruler limited in his powers, like the Governors-General of the Baltic region dependent on the Ostsee nobility, in Russia. In such circumstances, the only fighters for the rights of the indigenous population of the Baltic States were the guardians (a literal translation of the Latin term 'conservatives'). They were statesmen, whose views were expressed and rather even formed by Mikhail Katkov. Disagreeing with the 'Katkovs' on many issues of the Baltic, guardians supported the Slavophiles.

Of course, sooner or later the Russian guardians opposed the Ostsee dominance not only in the highest apparatus of the Empire but also with a special position in the Baltic 
States. The implementation of reforms in Russia and the growth of the national movement among the Baltic peoples raised the question of the need for reforms in the Ostsee provinces as well. The foreign policy situation - the strengthening of Prussia and the unification of Germany under its leadership - gave it a special sharpness. The reunification of Germany provoked the enthusiasm of Ostsee people, and for the first time in half a century, this circumstance of Russian rule in the region questioned the loyalty of the Ostseisians to Russia. In fact, back in 1848-1849, during the German revolution, the three Baltic Russian provinces were declared by the so-called Frankfurt Parliament to be part of the all-German Reich. At that time, the paper resolutions of this 'parliament' were not taken seriously. However, at that time, a new world power was rapidly rising in the form of the German Empire, and its claims to the possession of the "old German land" in the eastern part of the Baltic Sea had to be taken into account.

Thus, the Ostsee order became a threat to the territorial integrity of Russia. Conservative publicists opposed the Ostsee and not only did they engage in a confrontation with an influential group in the empire's elite, but they also encountered opposition.

4.

Katkov devoted 155 articles to the problems of the Baltic region in the Moscow $V e d o m o s t i$, the first of which was published in 1864, and the last in 1886. On the Ostsee issue, Aksakov's Moscow had 32 editorials only in 1869. This already testified to the bitterness of the struggle for the Baltic issue.

Until that time, in Russian and world scientific literature, there was a tradition to consider conservatives as purely official propagandists or officials who did not have their face. Meanwhile, the persecution of the conservative press clearly demonstrated the relationship between conservatives and the government. Since the entry into force of the Provisional Rules on the Press on April 6, 1865 (valid until 1905), it was conservative newspapers and magazines that were most affected by censorship. So, the newspaper Moscow of Ivan Aksakov had 9 censorship warnings, 3 suspensions in one year, and finally was banned. The magazine Citizen of V.P. Meshchersky had 24 censorship penalties and was closed from 1878 to 1882. The Moscow Vedomosti of M.N. Katkov got 11 penalties. In 1866, Katkov was suspended from editing. The newspaper Modern Izvestia of N.P. Gilyarov-Platonov had 13 prohibitions for sale and was suspended several times in publication. The Slavophile publications - the magazine Russian Conversation, the newspaper Day, and the Dostoevsky brothers' edition Time - were prohibited by censorship. The position of these publishing houses in the Ostsee issue largely contributed to the conflicts of conservatives in government censorship. 
In the 1860s and 1870s, Germany actively promoted the idea of reuniting the Reich with the Baltic provinces of Russia by a number of the Ostseisians who emigrated to their 'historical homeland'. Thus, Egor (Georg) Sivers, an Ostsee poet, professor at the Riga Polytechnic (and great-grandson of a Russian admiral of Peter's time), in the 1860s made several critical articles in the Baltiche Monatschrift, in which he emphasized the German character of the region. Julius Eckart, the editor of a German newspaper in Riga and the author of the book The Baltic Province of Russia, published in 1869 in German, wrote in the same spirit. Historian K. Schirren published a multi-volume extremely tendentious work Historical Origins of the Collapse of Livonian Independence. E. Kuttner published the work Vocation of Prussia in the East, which proved the rights of Prussia to the Baltic States and painted "the future of the German Ostsee provinces under Prussian rule".

Somewhat later, by the turn of the 19th and early 20th centuries, such plans were preached in Germany by a triumvirate of influential journalists, as well as university professors from the Russian Baltic States - T. Schiemann, I. Haller and P. Rohrbach. All three were considered the most widely read of German publicists. Schiemann edited the Krestovaya Gazeta, where Bismarck once worked, and Rohrbach was constantly read by Kaiser Wilhelm II. All three former Russian subjects wrote that Russia was outside the family of European peoples, their culture and civilization. Russian culture as such does not exist at all. Accordingly, it was impossible to treat Russians as white people. Russia should have been cut into pieces like an orange. In addition, since there are too many Russians, special measures should be taken to correct this situation in the future. Russian lands should become German, and the Slavs are only manure for the growth of German culture.

However, even these vicious Russophobes showed a hidden admiration for the Russians as a nation. Paul Rohrbach wrote that "apart from the British, history generally knows only two nations that have acquired a comparable national sense of self-worth, a similar providential awareness of their power - the Romans and, at least for a certain era, the leading classes of the Russian nation... [The Russians and the British] are accustomed, based on a long chain of their grandiose political and (real or imaginary) civilizing successes, to identify the cause of human development to a greater or lesser extent with their national position.” (Rohrbach, 1911)

5.

The head of the Ostsee emigrants in Prussia was the former Deputy Chairman of the Livonia High Court, von Bock, who, according to I. Aksakov, "organized a whole system of agitation of public opinion against Russia in Berlin.” (Aksakov, 1887)

Standing at the head of the Russian national press, "the practitioner of Slavophilism" Ivan Aksakov immediately drew attention to the Ostsee problem. His literary legacy 
includes more than two dozen articles on the Baltic issue. On June 2, 1862, in the first Ostsee article How to Understand the Baltic German Ideal of Russia, I.S. Aksakov said that the 'Ideal of Russia', which is preached by Baltic Germans, was based on a deep, serious and sincere sense of statism, the sense of loyalty and devotion of Germans to the state of the Empire, not the Russian people: "the fact that loyal to the Russian throne, as we have seen, they are preaching at the same time, fight to the death of the Russian nation; the faithful servants of the Russian state, they do not want to know the Russian Land. For them, Russia exists only as of the Russian Empire, and not as Russia, not as the Russian Land, under the protection of which there may be areas inhabited by other nationalities". Thus, the German ideal was "the embodiment of the abstract idea of the state, outside of the nation, such a Russia, in which there would be nothing Russian that stands out...".

I.S. Aksakov also drew attention to the situation of the aborigines of the region. It was no coincidence that one of his articles in the newspaper Day of November 27, 1865, is called "On What Basis is the Peasant of the Ostsee Region Deprived of the Rights that the Peasant Enjoys in the Rest of Russia?".

He was particularly indignant at the position of the Baltic Germans, expressed in the thesis that the Russians are barbarians, and the Germans are the enlightenment, the Russians are savages, and the Germans are civilized (Aksakov, 1887), and also statements of the European press about "oppression of Germans in Russia” (Aksakov, 1887).

I.S. Aksakov also drew attention to the striking similarity between the Baltic chivalry and the Polish gentry, as well as the claims of the Jews to 'equality', which meant the special domination of the Jews in all of Russia by analogy with the Ostsee provinces and the Western Region. As can be seen, any phobia always brings together some opponents. It should be noted that the demands of phobia are accompanied by the declaration of 'rights' and 'freedom'.

Aksakov pointed out that it is difficult not to notice the analogy of the "Polish and German activities". The similarity of the behaviour of Poles in the Western Region and Germans in the Ostsee region of the Russian Empire is striking:

- "both the Poles in the north-western provinces, and the Germans in the Baltic Pomerania are strangers and do not belong to the native nationality of the region";

- "Germans and Poles are lords in the region, in which they represent a significant minority";

- in their hands, "land property, social privileges and all the means of pressure on nonPolish and non-German masses of the people focuses";

- in their environment, "the desire region to polonise Russians and Lithuanians, and Germanize Latvians and Estonians in Baltic provinces in the North-West" was dominated; 
- "methods to translate native nationality in the Polish and German are almost the same: religion, school, the temptations of worldly benefits, threats, violence, persecution, humiliation...";

- "the upper classes, composed of people of a nationality, which is alien to the edge, i.e., Poles and Germans, obscured, and in the Baltic seaboard, continue obscuring and now, the masses of the rural population from the Russian government";

- $\quad$ "in these oppressed masses of the rural population, national hatred to their abusers - to the Polish gentry and German knights - is deeply implemented, a deep attraction to Russia and sincere faith in the Russian Tsar exist...” (Aksakov, 2002)

I.S. Aksakov emphasizes Samarin's words that "those who preach the need to tighten, curb and besiege Russian society by moving the apparatus of police power against it, at the same time, flirt with the Polish gentry and silently give up when meeting with the Baltic chivalry..." (Aksakov, 2002)

The Jews also aspired to the same role of masters, like the Ostsee knights and Polish gentry in their regions. I.S. Aksakov did not ignore this problem. So, in 1862, in the first article on the Baltic problem, he found the "similarity of the German view to the Jewish one" striking at first glance with its paradoxical nature: "The Jews, just like the Germans, do not recognize the Russian nationality in Russia and still discuss the issue if (for the Germans, it has long been resolved negatively!) Russians are really the masters in the Russian land? In their opinion, the Jews are just as much the masters of the Russian land as the Russians. This demand of the Jews ... is quite consistent with the German ideal of the abstract state." (Aksakov, 2002)

\section{6.}

Yuri Samarin continued fighting Ostsee philosophy. Having initiated the study of the Baltic issue in Letters from Riga, then he comprehensively investigated it in the issues of The Outskirts of Russia, published abroad in 1868-76, formulating the task of Russian policy in the Baltic States: guardianship and support Latvians and Estonians, the elements friendly to Russia, and their liberation from German influence. The fact that "Outskirts..." were released abroad is quite significant. By the way, Samarin received a reprimand for them personally from Alexander II. The appearance of this volume in Prague caused a scandal and a storm of indignation not only in the elites of St Petersburg. Y. Samarin, like twenty years ago, had to explain himself to the tsar.

The Ostseisians took the works of Samarin very painfully. Professor of the University of Dorpat, Carl Christian Gerhard Schirren wrote a whole book Livonia's Answer to $\mathrm{Mr}$ Samarin, in which he defended the inviolability of the former status of Livonia and the rest of the Baltic provinces. In the same year, 1868, the German nobility sent Alexander II an all-important address to remove the Samarin's 'slander'. It is interesting that shortly after 
the 'Livonia answer', he emigrated to Germany, where he died in 1910. Encouraged by the Baltic Germans, he began to search for documents relating to the history and upshot of the Northern War, as a result of which the Baltic lands gradually began to withdraw to the Russian Empire during the 18th century. According to Schirren's plan, evidence, extracts, and documents were to justify the Germans and thereby substantiate their claims to a special position in these provinces. However, as a result of many years of searching, the professor discovered too many unsightly facts and, as an honest scientist, admitted: "The Baltic Germans had more guilt than glory." Most of the huge archive collection had to be put on fire by the professor, so as not to inflict a serious blow to his fellow tribesmen.

In 1868, the book On the Rural Life of the Livonian Peasants, written by Friedrich JungStilling, Secretary of the Livonian Statistical Committee, was published in Riga, where it was proved that in several western countries, the well-being of agricultural workers did not reach the Livonian level. Jung-Schilling noted that "the income of one married rural worker in Livonia exceeds the income of a whole family of Prussian farmers". He wrote that in Belgium, even a married rural worker received less than a single farmhand in Livonia "despite the fact that life is much cheaper here". Written by the Livonian scholar was largely true. Indeed, in many indicators of economic development, the Baltic provinces were ahead of some European states. However, in general, this work of JungSchilling was aimed at proving the special role of the Ostseisians in the life of the region. The general implication was simple: only the Ostsee barons were capable of guiding the natives and bringing them to a high level of development and prosperity. In the United States, just before the Civil War of 1861-65, the slave owners of the South also wrote books about the fact that the Negroes on the plantations lived more affluently than the proletarians in the factories in the North. At the same time, convincing evidence and facts provided. So, Jung-Schilling's essay was a retaliatory blow in defence of the Ostsee claims.

In 1864-1865, the officialdom of the War Ministry of 'Russian Invalid', backed by the Minister of War D.A. Milyutin, played an active role in the campaign against the Ostseisians, but after the highest displeasure, the newspaper was forced to soften its position.

Finally, M.N. Katkov actively spoke on the pages of his issues. In 1869, in the midst of the controversy caused by the 'answer' of C. Schirren, he pointed out to the Russian reader the essence of the Ostsee demands that "it is known that the Baltic policy has now developed, concerning the circumstances, a special political terminology. Baltic politics agrees to call Russia by Reich and allow for it Reichseinheit (Imperial unity), but it does not want to know Russia as a state and allow for it state unity. Reich can serve as a collective name for the totality of many states that are randomly connected with each other, as, e.g., there was an Assyrian or Babylonian monarchy, as there was a Mongol Horde on the Volga, as today's Turkey and Austria, which has no internal basis for its 
existence and can be erased from the European map every minute. Another thing is 'Staat'. This is the individuality that the people acquire through the hard and long work of historical development, this is a whole, living, organic unity." To the arguments of the Ostseisians about the rights that Peter the Great had secured for them, Katkov reasonably replied that "Peter the Great had several urban communities and knightly societies that owned land temporarily, in the Baltic region.

Where were the people of these countries? Where was that social organization, which in every state goes from top to bottom and in which the national life of the country is expressed? There were no people than in these regions, and there could be no question of any nationality. The native population did not appear at all. There was no mention of them. They were completely disenfranchised beings, devoid of any civil, even human significance. The knights preferred to command them in their dark languages, rather than to bring them nearer and equalize them with themselves using the German language. So, they thought a little about national unity between the various elements of their country. Does the supreme power now have in the Baltic region? The former slaves, over whom their owners had the right of life and death, became, at least in idea, free beings. Numerous populations, which (at least in principle) got some civil rights, had come to light. From behind the privileged squads, who turn to the all-quickening sun and need the care, justice and mercy of an exalted and equal supreme power, the humbler of the proud and the comforter of all, appeared millions of people. Feudal orders were impossible. It requires a time-appropriate administration and a court that meets the highest requirements of citizenship and justice. Due to the diverse populations of the region, the issue of its state nationality arises. What government should be in this region - Russian or German? Which language should be the common, obligatory organ for all the diverse inhabitants of these provinces-Russian or German?” (Aksakov, 2002)

\section{Conclusion}

According to Russian conservatives, the solution of the Baltic issue was in the need to:

- adopt the Russian state in the Baltic region - management of the Russian model, common Russian law, Russian language as a state;

- equalize in the Baltic States in rights with the Germans, the indigenous population of the region and, in particular, in the first place, the Russians; to carry out land reform in the region - to give the land to the peasants on the Russian pattern of reform of 1861;

- introduce in schools the Russian language; to reform the court - the institution of the jury and election of local judges in the Russian sample;

- $\quad$ reform the city administration; 
- $\quad$ support Orthodoxy in the region.

The liberal press, especially the St Petersburg Vedomosti, edited by Valentin Korsh, declared the Ostsee issue far-fetched, the Baltic aborigines were declared 'European nations', and M.N. Katkov, I.S. Aksakov, and Y. Samarin were accused of 'chauvinism' and 'inciting national hostility'. As can be seen, Russian liberals have not come up with anything new over the past century and a half, blaming those who protect Russia's interests in the same terms.

The efforts of the guardians gradually began to bear fruit. Despite the resistance of the Ostseisians, who were supported by the influential P.A. Shuvalov, the government of the Empire finally began a policy of final incorporation of the Ostsee region into the empire, eliminating its features.

The Slavophil and protective press of Russia supported with great joy the weakening of German influence in the region and the development of local nationalities. There was only one sceptic, the famous in our time (but almost unknown in that era) Konstantin Leontiev. He wrote that "in the affairs of the Ostsee region, it now seems to me that we should prefer conditional justice, i.e., the legality associated with the traditions of this region, to absolute justice, i.e., the right of the German barons to prefer the Esto-Latvian democratic movement. The names of the German aristocracy are associated with the military and political greatness of Orthodox Russia, and the Esto-Latvian movement is associated with nothing but liberal fashion... if we ... in the Ostsee region, instead of feudal Europeism, which gave the Russian Tsars so many good generals and politicians, we introduce egalitarian, i.e., liberal Europeism, which, apart from lawyers, accusatory correspondents, 'real' mentors, etc., has given nothing and cannot give anything, then what kind of Russification is this?” (Leontiev, 1996)

However, these individual statements were drowned in the common chorus of approval of government policy in the Baltic region.

The German 'Baltic special life' (baltisches Sonderleben) was gradually becoming a thing of the past.

\section{References:}

Aksakov, I.S. (2002). About the 'Outskirts' of Y.F. Samarin. Moscow, ROSSPEN.

Aksakov, I.S. (1887). Complete works. Vol. 6. Moscow.

Barinov, I.I. (2017). Irredentism and the Transformation of Imperial Identity: The Ostsee

Region in the events of 1917. History and Modernity, 2, 191-210.

Belyaev, P.I. (1898). The general Imperial law and local Ostzei legalizations. Journal of the Ministry of Justice, 9, 121-167.

Boehm, M.H. (1915). Die Krisis des deutschbaltischen Menschen. Berlin: Grenzboten. 
Leontiev, K.N. (1996). The East, Russia and the Slavs: Philosophical and Political Journalism. Spiritual prose (1872-1891). Moscow: Republic.

Moscow Vedomosti, 141, 1869, June 28.

Rauch, G. von (1970). Geschichte der baltischen Staaten. Stuttgart: Kohlhammer.

Rohrbach, P. (1911). Deutschland unter den Weltvölkern.

Seraphim, A.E.W. (1908). Baltische Geschichte im Grundriss. Reval: Kluge. 